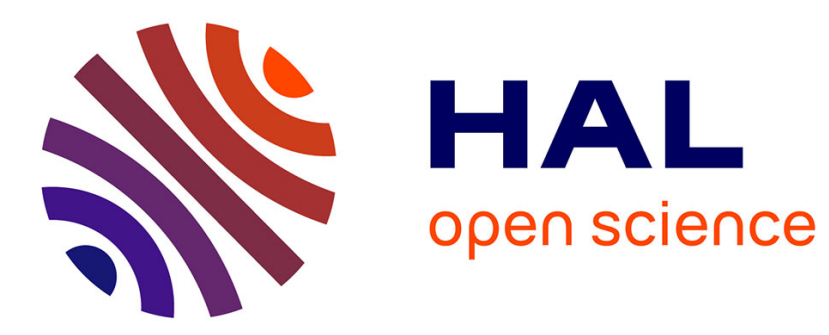

\title{
In vivo MRI tracking of exogenous monocytes/macrophages targeting brain tumors in a rat model of glioma.
}

\author{
Samuel Valable, Emmanuel L Barbier, Myriam Bernaudin, Simon Roussel, \\ Christoph Segebarth, Edwige Petit, Chantal Rémy
}

\section{To cite this version:}

Samuel Valable, Emmanuel L Barbier, Myriam Bernaudin, Simon Roussel, Christoph Segebarth, et al.. In vivo MRI tracking of exogenous monocytes/macrophages targeting brain tumors in a rat model of glioma.. NeuroImage, 2008, 40 (2), pp.973-83. inserm-00536177

\section{HAL Id: inserm-00536177 https://www.hal.inserm.fr/inserm-00536177}

Submitted on 22 Jun 2011

HAL is a multi-disciplinary open access archive for the deposit and dissemination of scientific research documents, whether they are published or not. The documents may come from teaching and research institutions in France or abroad, or from public or private research centers.
L'archive ouverte pluridisciplinaire HAL, est destinée au dépôt et à la diffusion de documents scientifiques de niveau recherche, publiés ou non, émanant des établissements d'enseignement et de recherche français ou étrangers, des laboratoires publics ou privés. 


\title{
In vivo MRI tracking of exogenous monocytes/macrophages targeting brain tumours in a rat model of glioma
}

\author{
Valable Samuel $^{1,2}$, Barbier Emmanuel ${ }^{1,2}$, Bernaudin Myriam ${ }^{3}$, Roussel Simon $^{3}$, \\ Segebarth Christoph ${ }^{1,2}$, Petit Edwige $^{3}$, Remy Chantal ${ }^{1,2}$
}

\footnotetext{
${ }^{1}$ Inserm, U836, Grenoble Institut des Neurosciences, Grenoble, F-38043 France;

${ }^{2}$ Université Joseph Fourier, Grenoble, F-38043 France;

${ }^{3}$ UMR-CNRS 6185, CERVOxy group "Hypoxia and cerebrovascular pathophysiology", University of Caen, CYCERON, Bd Henri Becquerel, BP5229, 14074 CAEN cedex.
}

\section{Corresponding author}

Dr C. REMY, PhD,

Grenoble Institut des Neurosciences (GIN)

Centre de Recherche INSERM U 836 UJF-CEA-CHU

Equipe 5: Neuroimagerie Fonctionnelle et Métabolique

CHU - Pavillon B; BP 217

38043 Grenoble Cedex 9

France

Tel: 33476765963

Fax: 33476765896

chantal.remy@ujf-grenoble.fr 


\section{Abstract}

This study has shown that murine monocytes/macrophages (Mo/Ma) can be labelled simply and efficiently with large, green-fluorescent, micron-sized particles of iron-oxide (MPIO). Neither size nor proliferation rate of the Mo/Ma are significantly affected by this labelling. The labelled Mo/Ma have been administered intravenously to rats that had developed a glioma following stereotactic injection of $\mathrm{C} 6$ cells. The labelled Mo/Ma were shown to target the brain tumours, a process that could be monitored non invasively using $\mathrm{T}_{2}{ }^{*}$-weighted MRI. MRI observations were confirmed by Prussian-blue staining, lectin staining and fluorescence histology. Overall, the results of this study suggest that the use of Mo/Ma may be envisaged in the clinic for vectorizing therapeutic agents toward gliomas. 


\section{Introduction}

Despite significant progress made in the understanding of the aetiology of glioma (Sanai et al., 2005), brain tumours still present a very poor prognosis. One of the challenges in anti-tumoural therapy is maintaining an elevated concentration of therapeutic agents at the tumour site, and preventing their spread into healthy tissue (Minchinton and Tannock, 2006; Ohlfest et al., 2005). In this context, cell-based vectorization of therapeutic agents has great potential. Cellular therapy allows sustained production of a desired molecule, possibly mediated by genetic engineering. For example, genetically modified mesenchymal or neural stem cells overexpressing interleukin-2 (Nakamura et al., 2004) or interleukin-12 (Ehtesham et al., 2002) may be used to inhibit glioma growth. Therapeutic cells may be injected directly within the vicinity of the tumour. A weakness of this approach lies in that it is not easy to translate it into clinical routine and that the injected cells do not readily distribute over the entire tumour mass. Alternatively, one may choose an intravenous route and take advantage of the chemoattractive properties of the glioma (Bajetto et al., 2006; Krop, 2006).

Systemic administration of therapeutic cells presents the advantage of being more convenient in the clinic. The use of circulating cells such as monocytes/macrophages (henceforth referred to as Mo/Ma) presents several features of interest in the case of brain tumours. (i) Mo/Ma are attracted by brain tumours (Badie and Schartner, 2000; Strik et al., 2004), similarly as what happens with astrocytes, microglia and neural stem cells (Badie and Schartner, 2001; Ehtesham et al., 2002), non-cerebral cells such as stromal stem cells (Nakamura et al., 2004; Zhang et al., 2004) and other circulating cells such as lymphocytes (Watanabe et al., 1998). As an example, two weeks after tumour implantation in a rat brain, endogenous macrophages are found within the tumour or at the tumour periphery, while they are not detected in the non tumoural hemisphere - an 
observation suggestive of local synthesis of chemoattractive factors (Bajetto et al., 2006). (ii) The level of Mo/Ma infiltration seems independent of the immunogenicity of the glioma model (inbred, syngeneic RG2 model compared to an outbred, immunogenic C6 model) (Badie and Schartner, 2000). (iii) In view of a potential clinical transfer, Mo/Ma present the advantage over mesenchymal or neural stem cells that they are circulating cells which can be easily sampled and reinjected into the blood stream. The use of such cells is considered to present limited risk (Burke et al., 2002; Burke, 2003) given that microglia/macrophage accumulation occurs naturally in response to glioma development (Badie and Schartner, 2000; Strik et al., 2004) and given that exogenous macrophages will either move towards inflammatory body regions or towards reticuloendothelial organs for elimination (Audran et al., 1995; Chokri et al., 1989).

The use of Mo/Ma as a vehicle for gene therapy against glioma thus appears to be a therapeutic strategy of interest. In patients, implantation of autologous $\mathrm{Mo} / \mathrm{Ma}$ may furthermore be considered. While some understanding of the reactivity of endogenous macrophages in glioma has been gained from immunohistochemistry (Badie and Schartner, 2000; Strik et al., 2004), there is very little information about exogenous Mo/Ma used to therapeutically target gliomas.

This study aimed to determine whether intravenously injected Mo/Ma could target a brain tumour and whether these cells can be detected in vivo, using MRI. MRI has recently emerged as a powerful tool for in vivo cell tracking (Hill et al., 2003; Modo et al., 2005) and the concomitant development of new intracellular contrast agents has allowed the in vivo detection of very few cells (Heyn et al., 2006; Shapiro et al., 2006). In the present study, Mo/Ma were labelled with micron-sized fluorescent particles of iron-oxide (MPIO), allowing detection by MRI as well as by histology. After in vitro assessment of the efficiency and the innocuity of the labelling procedure, we used ex vivo and in vivo 
MRI in combination with histology to demonstrate and to monitor the capacity of a rat brain tumour to attract intravenously administrated Mo/Ma. 


\section{Material and Methods}

\section{Animal Handling}

All animal care procedures were in agreement with the instructions provided by the local committee of animal health care (licenses: senior researcher authorization 380508 , laboratory A3851610004 and animal care facility B3851610003). Animals were manipulated under anesthesia (5\% isoflurane induction, $2 \%$ for maintenance in $70 \%$ air / $30 \%$ oxygen). Their rectal temperature was maintained at $37.0 \pm 0.5^{\circ} \mathrm{C}$ with a feedbackcontrolled heating pad (water blanket in the MRI scanner) connected to a rectal probe. A total of 24 animals was used for the study.

\section{Glioma Model}

The C6 glioma (ATCC, CCL-107) model was used as orthotopic brain tumour model. Male Wistar rats (175-200g) were placed on a stereotactic head holder and a scalp incision was performed along the median line. A $1 \mathrm{~mm}$ diameter burr hole was drilled in the skull, $3 \mathrm{~mm}$ laterally from the bregma. The cell suspension $\left(10^{5}\right.$ cells in $\left.5 \mu \mathrm{l}\right)$ was injected within 5 minutes using a dental needle (30G) connected to an Hamilton syringe. The injection site was the right caudate nucleus, at a depth of $6 \mathrm{~mm}$ under the dura. The needle was slowly removed 5 minutes after the end of the injection and the burr hole was eventually plugged with dental cement.

\section{Cell culture and magnetic labelling}

Murine P388-D1 Mo/Ma (ATCC, CCL-46) were seeded at a concentration of $0.8 \times 10^{6}$ cells $/ \mathrm{ml}$ in Dulbecco Modified Eagle Medium supplemented with $10 \%$ of fetal bovine serum (Invitrogen, France) and $2 \mathrm{mM}$ Glutamine (Invitrogen, France). Cells were labelled with MPIO $(0.9 \mu \mathrm{m}$ in diameter, $63.4 \%$ magnetite w/w; Bangs Laboratory®, Fisher, IN, USA). These particles are poly-disperse carboxylated iron-oxide core particles containing the Dragon green fluorophore (excitation wavelength $480 \mathrm{~nm}$; 
emission wavelength $520 \mathrm{~nm})$. Particles $(1,2,5,10$, and $25 \mu$ l corresponding to 6.3 , $12.7,31.7,63.4$, and $158.4 \mu \mathrm{g}$ of iron respectively) were added to the cellular suspension $\left(2.5 \times 10^{6}\right.$ cells in one ml). After 18 hours of incubation at $37^{\circ} \mathrm{C}$ in $5 \% \mathrm{CO}_{2}$, the cellular suspension was withdrawn from the wells and rinsed three times with phosphate buffer saline (PBS, Sigma, France) and centrifugated at $600 \mathrm{rpm}$, so as to remove all particles not having been taken up by the cells.

\section{Labelling efficiency and cellular viability}

Labelling efficiency was assessed using epifluorescence microscopy and fluorescenceactivated cell sorting (FACS) analysis. Green fluorescence was measured with a FACSCalibur (Becton-Dickinson) on a fixed number of 25000 cells. Cell size was estimated using the forward scatter parameter. Cellular tolerance to labelling was evaluated using proliferation assays. Non confluent cells were labelled $(21 \mu \mathrm{g}$ of iron per $0.8 \times 10^{6}$ cells in one $\left.\mathrm{ml}\right)$, rinsed and replated at the same concentration. Cells were counted at Days 1, 2, 3 and 4 post-labelling with a Neubauer-counting chamber and phase-contrast microscopy.

\section{Cell iron content}

After labelling, cells were hydrolysed for $18 \mathrm{~h}$ in $\mathrm{HCl} / \mathrm{PBS}$ (vol/vol) at $120^{\circ} \mathrm{C}$ and the suspension was immobilized by the adjunction of agarose powder $(1 \% \mathrm{w} / \mathrm{v})$. One $\mathrm{ml}$ of labelled cell solution and one $\mathrm{ml}$ of unlabelled cell suspension were allowed to polymerize in vials (cell samples). The same procedure was applied to saline solutions (calibration samples) with known concentrations of MPIOs.

Two approaches were used to assess the iron content of the samples. With the first, $T_{1}$, $T_{2}$ and $T_{2}{ }^{*} M R$ relaxation times were measured on the calibration samples (see below) and calibration curves were derived from linear fits of the data. The iron content of the cells was then determined from the relaxation time measurements and the calibration curves. In the second, the iron content was determined using Inductible Coupled 
Plasma/ Atomic Absorption Spectroscopy (ICP-AAS). After mineralization in nitric acid at $70^{\circ} \mathrm{C}$ for 8 hours, the iron concentration was measured on a Hitachi 8270 spectrometer.

\section{Mo/Ma injection}

Mo/Ma were injected via the tail vein. A small incision was realized in the tail, and a lateral vein was exposed. A catheter was introduced in the vein, cells were slowly injected $\left(2 \times 10^{6} \mathrm{cells} / 100 \mu \mathrm{l}\right)$ and the vein was sutured. Mo/Ma were injected either at day 4 or at day 11 after tumour cell implantation.

\section{MR experiments}

Experiments were performed in horizontal bore magnets, operating at $2.35 \mathrm{~T}(40 \mathrm{~cm}$ bore diameter) and at $7 \mathrm{~T}$ (20 $\mathrm{cm}$ bore diameter). Both magnets were equipped with actively shielded magnetic field gradient coils (Magnex Scientific Ltd., Oxford, UK) and they were interfaced to a SMIS console (SMIS Ltd, Guildford, UK).

Relaxation time measurements were performed at $2.35 \mathrm{~T}$ using a volume coil. $\mathrm{T}_{1}$ values were computed from data acquired with an Inversion/Recovery MR sequence (Haase, 1990) (22 inversion times ranging from 15 to $8000 \mathrm{~ms}$ ). $\mathrm{T}_{2}$ measurements were performed using a Carr-Purcell-Meiboom-Gill sequence (400 echoes, inter-echo spacing of $900 \mu \mathrm{sec}) . \mathrm{T}_{2}{ }^{*}$ values were measured with a multi gradient-echo MR sequence (7 echoes, TR/TE $=6000 /[6,12,18,24,30,36,42 \mathrm{~ms}] . \mathrm{T}_{1}, \mathrm{~T}_{2}$ and $\mathrm{T}_{2}{ }^{*}$ estimates were obtained by fitting a mono-exponential model function to the data. Matlab 7 (The MathWorks, Inc., Natick, NA) was used for data analysis.

Brain imaging was performed either at $2.35 \mathrm{~T}$ (linear volume coil for excitation (internal diameter $79 \mathrm{~mm}$ ) / surface coil for detection (Rapid Biomedical GmbH, Rimpar, Germany)), or at $7 \mathrm{~T}$ (home made surface coil both for excitation and detection). Measurements were done either ex vivo on a paraformaldehyde fixed brain (intracardiac perfusion) or in vivo, at least three days after intravenous administration of macrophages. With this delay, Mo/Ma were given the time to migrate toward the tumour 
(Clark et al., 1993; Phillips et al., 2000). 3D $\mathrm{T}_{2}{ }^{*}$-weighted gradient-echo MR sequences were used for cell detection and multiple slice $\mathrm{T}_{2}$-weighted spin-echo MR sequences were used for detection and delineation of the tumours. Ex vivo, $\mathrm{T}_{2}{ }^{*}$-weighted MR measurements were performed either at $7 \mathrm{~T}$ or at 2.35T. At $7 \mathrm{~T}$, the major MR imaging parameters were: TR/TE $=1600 / 25 \mathrm{~ms}$, number of averages $(\mathrm{NA})=4$, nominal resolution: $78 \times 78 \times 117 \mu \mathrm{m}^{3}$. At $2.35 \mathrm{~T}$, they were the following: $\mathrm{TR} / \mathrm{TE}=600 / 25 \mathrm{~ms}$, $\mathrm{NA}=1$, nominal resolution: $105 \times 105 \times 185 \mu \mathrm{m}^{3}$. In vivo, $\mathrm{T}_{2}{ }^{*}$ - as well as $\mathrm{T}_{2}$-weighted $\mathrm{MR}$ measurements were always performed at 2.35 T. Major parameters of the $\mathrm{T}_{2}{ }^{*}$-weighted MR sequence were: $\mathrm{TR} / \mathrm{TE}=100 / 25 \mathrm{~ms}, \mathrm{NA}=4$, nominal resolution: $203 \times 203 \times 390 \mu \mathrm{m}^{3}$. Major parameters of the $T_{2}$-weighted MR measurements were: TR/TE $=2000 / 80 \mathrm{~ms}$, $\mathrm{NA}=1$, nominal resolution: $203 \times 394 \times 1000 \mu \mathrm{m}^{3}$.

\section{Histochemistry}

Fixed brains were cryoprotected by immersion in a $30 \%$ sucrose solution (Sigma, France) for $48 \mathrm{~h}$, before storage at $-80^{\circ} \mathrm{C}$. Microglia/macrophages were detected on $20 \mu \mathrm{m}$ thick coronal brain sections following a lectin-binding protocol (Zelivyanskaya et al., 2003). After saturation of the endogenous peroxidase, microglia/macrophages were visualized using peroxidase-linked isolectin B4 (isolated from Bandeiraea simplicifolia GS-I-B4, Sigma, France), as described in (Bernaudin et al., 1999). Iron-loaded cells were detected using Prussian blue staining. Slices were incubated with $2 \%$ potassium ferrocyanide (Perl's reagent, Sigma, France) in $2 \% \mathrm{HCl}$, washed and counterstained with erythrosin.

\section{Data analysis}

Results obtained in vitro are expressed as Mean +/- SD and are representative of three independent experiments. Tumour volumes were obtained by delineating the tumours on the set of $\mathrm{T}_{2}$-weighted MR images from adjacent slices containing the lesion, counting the pixels within the tumour boundaries, and scaling with the volume per pixel. 
Histograms of the $\mathrm{T}_{2}{ }^{*}$-weighted MR signal intensities of the tumours were obtained using the tumour boundaries delineated on the $T_{2}$-weighted MR images, for the Mo/Ma $(n=4)$ and saline injected animals $(n=4)$, respectively. The student $t$-test was used for statistical analysis. For the imaging experiments, the number of animals studied is mentioned in each figure caption. 


\section{Results}

\section{Labelling efficiency}

$\mathrm{Mo} / \mathrm{Ma}$ were exposed to various concentrations of the iron-oxide particles (from $6.3 \mu \mathrm{g}$ to 158.4 $\mathrm{\mu g}$ of iron per $\left.2.5 \times 10^{6} \mathrm{cells}\right)$, for $18 \mathrm{~h}$ at $37^{\circ} \mathrm{C}$. Relative iron uptake by the cells was estimated from $\mathrm{T}_{2}{ }^{*}$ measurements on the washed and eventually hydrolysed cells. $\mathrm{T}_{2}{ }^{*}$ was found to decrease from $152.9 \pm 50.6 \mathrm{~ms}$ in the absence of particles to $24.8 \pm 11.4 \mathrm{~ms}$ in the presence of $63.4 \mu \mathrm{g}$ of iron in the culture medium (Table 1). Increasing the iron concentration to $158.5 \mu \mathrm{g} / \mathrm{ml}$ did not further reduce $\mathrm{T}_{2}{ }^{*}$. For the ensuing experiments, we therefore chose for incubating the cells with $63.4 \mu \mathrm{g}$ of iron per $2.5 \times 10^{6}$ cells. As shown in Fig. 1, all cells detected with phase-contrast microscopy (Fig. 1A) exhibit bright green fluorescence (Figs. 1B and 1C), an indication of the uptake of MPIO. Confocal microscopy analysis indicates cytoplasmic accumulation of the particles (Figs. 1B and 1D). Flow cytometry data show that $99.8 \%$ of cells are green-fluorescent (Fig. 1G). The presence of iron inside the cells has further been ascertained by Prussian blue staining (Fig. 1F, labelled cells vs Fig. 1E, unlabelled cells).

The mean labelling measured using MRI is $2.9 \mathrm{pg}$ of iron per cell (min 2.3 and max $3.9 \mathrm{pg}$ ). ICP-AAS quantification yields $2.8 \mathrm{pg}$ of iron per cell, in excellent agreement. Assuming that each particle contains about $0.3 \mathrm{pg}$ of iron, cells thus contain on average about 10 particles.

\section{Impact of labelling on cells}

Cell size was assessed by fluorescence-activated cell sorting, using the forward scatter parameter. Distributions from labelled and from unlabelled cells superimpose well (Fig. $2 A)$, suggesting no major effect of labelling on cell size.

Cell proliferation is interrupted as long as there are particles in the culture medium (Fig. $2 \mathrm{~B} ; \mathrm{t}=0-20 \mathrm{~h}$ ). Following cell washing, cell proliferation resumes and lasts until $72 \mathrm{~h}$ 
(Fig. 2B; $t=20 \mathrm{~h}-72 \mathrm{~h}$ ). The population doubling-times in the exponential phase are very similar for control $(19.9 \pm 4.9 \mathrm{~h})$ and for labelled cells $(20.8 \pm 5.8 \mathrm{~h})$. Trypan blue exclusion shows similar cell death in the labelled and in the control groups (i.e. less than $3 \%$ of dead cells for both groups). FACS analyses performed daily up to 4 days after labelling indicate a daily reduction of the mean fluorescence intensity by about a factor two under proliferating conditions (Fig. 2C) and relatively constant fluorescence under non-proliferating conditions (Fig. 2E). The correlation of cell population growth with the loss in fluorescence intensity per cell is further illustrated in Fig. 2E. The doubling-time (about 20 hours) of the cell number and the daily reduction of the fluorescence intensity by a factor two suggest an even distribution of the particles between daughter cells. Thus, assuming about 10 particles per cell at Day 1, each cell should contain on average about one particle at Day 4 . This is in agreement with the fact that the number of fluorescent cells is constant up to Day 4. Finally, when the cells are maintained at high concentration (low proliferation rate), they remain labelled during a similar observation window of 4 days ( $99.8 \%$ of labelled cells at 4 days).

\section{Ex vivo detection of intravenously administered labelled Mo/Ma}

Inoculation of tumour cells at Day 0, injection of labelled MoMa at Day 4, imaging at Day 7. $\mathrm{T}_{2}{ }^{*}$-weighted MR imaging was performed on PFA-fixed brains at $7 \mathrm{~T}$. The tumour exhibits a significant reduction of the MR signal intensity (Fig. 3A; arrow). Dark red lectin staining indicates a strong inflammatory response within an area corresponding to the hypointense tumour area observed on the $\mathrm{T}_{2}{ }^{*}$-weighted MR image (Fig. 3B). Prussian blue staining performed within the same area on an adjacent coronal section demonstrates the presence of iron loaded cells (dark blue spots) within the brain tumour (Fig. 3C), suggesting that the loss of MR signal intensity is likely due to the accumulation of labelled Mo/Ma. As was anticipated, a strong Prussian blue coloration appears in the 
spleen of the rats having received the Mo/Ma injection (Fig. 3E), while no such staining is found in the spleen of control rats (Fig. 3D).

Inoculation of tumour cells and of saline at Day 0, injection of labelled Mo/Ma at Day 4, imaging at Day 9. To determine whether $\mathrm{Mo} / \mathrm{Ma}$ are attracted specifically toward the tumourous tissue or also by inflammation induced by the mere injection procedure, tumour cells were implanted into the right striatum while saline was injected into the contralateral striatum. After four days, magnetically labelled Mo/Ma were injected intravenously and the brains removed on Day 9. Visual inspection of the ex vivo $\mathrm{T}_{2}{ }^{*}-$ weighted MR images permits detection of spots of signal drop along the saline (left hemisphere) and tumour (right hemisphere) injection tracts (black arrows in Figs. 4A and 4B), at the inferior part of the corpus callosum and at the tumour rim, mainly at the side near to the ventricle (white arrows in Figs. 4B and 4C). Importantly, no signal drop is observed in the striatum of the saline injected (left) hemisphere. Signal drops are strongest along the injection tracts - likely a reflection of the tropism of the Mo/Ma for inflammation due to the injection. In the Prussian blue stained and erythrosin counterstained images, control striatum exhibits sparse, dark blue, spots from ironloaded Mo/Ma (Fig. 4D) while tumour striatum exhibits a much higher density of these spots (Fig. 4E). The iron-loaded Mo/Ma appear as green-cyan spots on a dark blue background, instead, on the Hoechst 33342 counterstained fluorescence image of tumour striatum (Fig. 4F). Finally, the lectin stained and erythrosin counterstained images displayed as insets in Figs. 4D and 4E exhibit dark spots from stained macrophages and microglia. Overall, these results illustrate the capacity of circulating, labelled Mo/Ma to target the brain tumour.

\section{In vivo detection of intravenously administrated labelled Mo/Ma}

Inoculation of tumour cells at Day 0, injection of labelled MoMa at Day 4, imaging at Day 7. Visual inspection of the $T_{2}{ }^{*}$-weighted $M R$ images permits detection of 
hypointense spots within the tumour of Mo/Ma injected animals (Fig. 5A, white arrow). Location of the hypointensities within the tumour may be ascertained on the $T_{2}$-weighted MR image from the same slice (Fig. 5C). No such signal drops in the tumour are observed if no Mo/Ma were injected (control rats) (Fig. 5B; corresponding $\mathrm{T}_{2}$-weighted image in Fig. 5D). Both Prussian blue staining (blue spots on a pink erythrosin counterstained background; Fig. 5E) and fluorescence (green spots) (Figs. 5F and 5G) show the presence of numerous labelled cells in the tumour (appearing as a hyperintense blue background with the Hoechst counterstaining in Fig. 5G). The tumour volume still being relatively small at Day 7 (less than $10 \mathrm{~mm}^{3}$ ), the exogenous Mo/Ma distributed all over the tumour mass (Fig. 5E). When viewing the Prussian blue stained / erythrosin counterstained images (Fig. 5E) at increased magnification factor, the blue spots (corresponding to the iron particles) appear to be located in the cytoplasm of the cells, suggesting an intracellular location of these particles (Fig. 5E, inset).

Inoculation of tumour cells at Day 0, injection of labelled Mo/Ma at Day 11, imaging at Day 14. Tumour volume on Day 14 ranged between 25 and $70 \mathrm{~mm}^{3}$. Labelled Mo/Ma are detected in the $\mathrm{T}_{2}{ }^{*}$-weighted images all along the injection tract within the cortex (Fig. 6B). The tumour appears darker in the Mo/Ma-receiving rats (Figs. 6A and 6B, two different rostro-caudal positions) than in saline-injected rats (Fig. 6C). Histograms of the $T_{2}{ }^{*}$-weighted MR signal intensities of the tumours, for the Mo/Ma $(n=4)$ and saline injected animals $(n=4)$, respectively, further illustrate the reduced signal intensities observed in the tumours of the Mo/Ma injected animals (Control rats: $69.2 \pm 13.4$ a.u.; Mo/Ma injected rats: $58.2 \pm 11.7$ a.u.). Tumour location and extension may be verified on the $\mathrm{T}_{2}$-weigthed MR images (Figs. $6 \mathrm{E}$ and $6 \mathrm{~F}$, respectively). Strongest reduction of signal intensity in the $\mathrm{T}_{2}{ }^{*}$-weighted MR images is found just below the corpus callosum and near to the ventricle (Fig. 6B, white arrows). Prussian blue staining performed on the corresponding frozen sections confirms that iron-loaden cell density is higher at the 
periphery than in the centre of the tumour, in particular below the corpus callosum and near to the ventricle (Fig. 6D). 


\section{Discussion}

\section{Cell labelling}

In this study, we have chosen to label the cells with micron-sized particles of iron-oxide. Using this type of cell labels presents a double interest. First, MPIOs can be detected by a variety of imaging modalities, in vivo (by MRI) as well as ex vivo (by fluorescence microscopy, by Prussian blue staining microscopy and equally by MRI). Second, the large iron core (diameter of about $1 \mu \mathrm{m}$ ) strongly affects homogeneity of the static magnetic field applied in magnetic resonance experiments, thus allowing the detection of single cells by MRI (Heyn et al., 2006; Shapiro et al., 2006; Wu et al., 2006).

Efficient labelling of the murine P388-D1 Mo/Ma cell line was achieved by adding the iron particles to the cellular medium. This simple procedure has led to a labelling efficiency nearing $100 \%$, with a mean iron content per cell of about $2.9 \mathrm{pg}$. Other studies with similar (Heyn et al., 2005) or different cell types achieved similar labelling performance, using however more sophisticated labelling procedures, such as with transfecting agents (Anderson et al., 2005). While nano-sized particles have been shown to enter the cells by micropinocytosis (Arbab et al., 2006), the particular mechanisms of endocytosis of MPIOs have, to our knowledge, not yet been addressed. The capacity of the cells to incorporate more or less particles depends on the nucleocytoplasmic volume ratio (about 1 in the case of Mo/Ma). For example, a higher cellular iron content using a similar labelling procedure may be obtained with hepatocytes (Shapiro et al., 2006), i.e. cells that are characterized by a low nucleocytoplasmic volume ratio.

MPIOs were shown to distribute well among daughter cells, in accordance with observations made in other studies (Hinds et al., 2003). The fraction of labelled cells 
under proliferation conditions remains elevated for at least four days (Figure 2C) while the fluorescence and thus the iron content of the cells is reduced daily by about a factor 2.

Despite the incorporation of iron into the cells, no cellular toxicity was observed (using Trypan blue), in agreement with similar observations in other studies (Hinds et al., 2003). After cell washing following MPIO uptake, the population doubling-time is similar to that of control cells (about 20 hours). The cellular tolerance to the MPIO is likely due to their inert matrix preventing degradation and cell death consequent to iron dissemination within the cells. Finally, under the simplifying hypothesis that cells and particles are spheres with diameters of $10 \mu \mathrm{m}$ and $0.9 \mu \mathrm{m}$, respectively, the 10 particles take up less than $1 \%$ of the cell volume. With the imaging techniques used, any changes in cell size due to labelling were therefore undetectable.

\section{Cell tracking}

In this study, exogenous Mo/Ma were labelled. We may not rule out that the MPIO may have exchanged between exogenous cells and other endogenous circulating cells, a phenomenon having been observed to occur with USPIOs (Moore et al., 2000). Even under the hypothesis that detected MPIO were representative of exogenous $\mathrm{Mo} / \mathrm{Ma}$, it was not possible to evaluate the ratio of exogenous to endogenous Mo/Ma due to the difficulty to superimpose lectin and Prussian blue stainings and fluorescence (Stroh et al., 2006).

Massive iron deposition in the spleen and in the liver (not shown) was found three days after intravenous injection of the labelled $\mathrm{Mo} / \mathrm{Ma}$, an observation consistent with the Mo/Ma homing towards the reticulo-endothelial system on their way to elimination from the body (Burke et al., 2002; Burke, 2003). Labelled Mo/Ma were however also detected within the tumour at three and at five days after injection, both with MRI and with histology. This kinetics of the colonisation of brain tumour by labelled $\mathrm{Mo} / \mathrm{Ma}$ is in 
accordance with the kinetics characterizing these cells in other brain pathologies (Clark et al., 1993; Phillips et al., 2000). Our results demonstrate that exogenous Mo/Ma infiltrate not only small tumours (tumour volumes below $10 \mathrm{~mm}^{3}$ ) but also larger ones (Day 11, volumes ranging between 25 and $70 \mathrm{~mm}^{3}$ ). The entire tumour mass is invaded by the labelled Mo/Ma, with a higher density at the rim of the tumour. To rule out a possible attraction of the labelled cells by inflammation caused by the mere injection procedure, we performed control experiments whereby we injected saline in the left striatum of animals having been injected tumoural cells in the right striatum. Labelled Mo/Ma were detected along both needle tracts at the cortical level, but only in the right, i.e. in the tumoural, striatum. Moreover, fewer cells were found along the saline tract than along the tumour cell tract. These observations are a strong indication of $\mathrm{Mo} / \mathrm{Ma}$ cells targeting the tumour, in line with observations made using other cells (Zhang et al., 2004). The feature of tumour targeting results likely from local synthesis of chemoattractive factors (Tabatabai et al., 2005) in inflammation (Badie and Schartner, 2000; Strik et al., 2006) and/or in hypoxia (Serganova et al., 2004), as suggested by the accumulation of $\mathrm{Mo} / \mathrm{Ma}$ in a wide variety of pathologies for which inflammation and hypoxia are well described (such as wound healing (Crowther et al., 2001), atherosclerotic plaques (Tsukamoto et al., 1996) but also cerebral pathologies such as stroke (Myers et al., 1991; Stroh et al., 2006) and Azheimer disease (Kadiu et al., 2005))

Haemorrhage may lead to signal loss in $\mathrm{T}_{2}{ }^{*}$-weighted MR images in a fashion very much similar to what happens with the MPIO. This difficulty is illustrated in Figure 7, showing two $\mathrm{T}_{2}{ }^{*}$-weighted MR images from the tumour in a control rat (no Mo/Ma injection) and corresponding histological slides. The MR signal loss in the tumour is in this case due to haemorrhage, illustrating that under our experimental conditions, i.e. with the particular cells used and cell loading achieved and with the particular MR parameters applied, a 
possible confound exists between haemorrhage and iron loaded Mo/Ma. Histological analysis allows to distinguish with certainty haemorrhage from the presence of labelled cells (Stroh et al., 2006) .

With the iron content of the Mo/Ma achieved in the present study, in vivo cell tracking in the brain has proven difficult. This difficulty may result from our choice to use the intravenous route for cell injection. The number of Mo/Ma entering the brain may thus be limited, resulting in a contrast-to-noise ratio that is lower than in a setup whereby cells would be injected locally (Tang et al., 2003). With our method, the detection threshold could however still be enhanced, using MR sequences presenting better iron sensitivity (Foster-Gareau et al., 2003; Heyn et al., 2005). First, we have realized that our choice of a $25 \mathrm{~ms}$ echo-time is sub-optimal, considering that tissue $\mathrm{T}_{2}{ }^{*}$ is nearly twice this echo time at 2.35 T and that optimal contrast with respect to normal tissue would require an echo-time about tissue $\mathrm{T}_{2}{ }^{*}$. Second, we have been led to use a rather short repetition time. Our initial objective being to acquire the $3 D T_{2}{ }^{*}$-weighted MR images of the brain in about one hour, this constraint imposed to us an upper limit of about $400 \mathrm{~ms}$ for the repetition time (assuming a single measurement per phase-encoding step), considering the imaging matrix chosen $(128 \times 128 \times 64)$. To prevent having to reject full measurements in case of excessive animal motion, we decided to further reduce the repetition time by a factor of four and to average four sequential, identical, measurements instead. In taking this decision, we were aware that we would sacrifice contrast to noise ratio between CSF and regions containing labelled cells. We considered that the benefit of being able to retain most of the data in case of excessive animal motion outweighed the ensuing reduction in this contrast-to-noise ratio. Other strategies to improve the detection threshold may include using higher field strengths (Shapiro et al., 2004) and/or using alternative MR pulse sequences such as TRUE-FISP or FIESTA (Heyn et al., 2005). 
The detection of cells labelled with iron particles relies upon detecting MR signal drops in $\mathrm{T}_{2}{ }^{*}$-weighted $\mathrm{MR}$ images. An alternative labelling approach would consist in using gadolinium-based contrast agents (Aime et al., 2002; Modo et al., 2004; Terreno et al., 2006). With these agents, the detection of labelled cells would rely upon detecting MR signal enhancement in $T_{1}$-weighted MR images. While appealing at first sight, the use of these contrast agents appears even less effective for the detection of individual or of a few cells (Anderson et al., 2005).

\section{Conclusion}

In conclusion, this study has shown that murine monocytes/macrophages (Mo/Ma) can be labelled simply and efficiently with large, micron-sized iron-oxide particles. Neither cell size nor cell proliferation rate are significantly affected by this labelling. The labelled Mo/Ma have been administered intravenously to rats that developed a C6 glioma following stereotactic injection of $\mathrm{C} 6$ cells. The labelled Mo/Ma were shown to target the brain tumours, a process that could be monitored non invasively using MRI. MRI observations were confirmed by histology. Overall, the results of this study suggest that the use of monocytes/macrophages may be envisaged in the clinic for vectorizing therapeutic agents toward gliomas. 


\section{Acknowledgments}

One of the authors (S.V.) benefited from a post-doctoral grant awarded by "La Ligue Contre le Cancer". Authors gratefully acknowledge generous help from the "Département de Biologie Intégrée" (Grenoble University Hospital) in the FACS analysis and the ICP-AAS quantifications. The authors wish to thank the "Association pour la

Recherche sur le Cancer", the "Region Rhône-Alpes", and the "Cancéropôle Lyon Auvergne Rhône-Alpes" for their financial support. 


\section{Reference List}

Aime, S., Cabella, C., Colombatto, S., Geninatti, C.S., Gianolio, E., Maggioni, F., 2002. Insights into the use of paramagnetic $\mathrm{Gd}(\mathrm{III})$ complexes in MR-molecular imaging investigations. J.Magn Reson.Imaging 16, 394-406.

Anderson, S.A., Glod, J., Arbab, A.S., Noel, M., Ashari, P., Fine, H.A., Frank, J.A., 2005. Noninvasive MR imaging of magnetically labeled stem cells to directly identify neovasculature in a glioma model. Blood 105, 420-425.

Arbab, A.S., Liu, W., Frank, J.A., 2006. Cellular magnetic resonance imaging: current status and future prospects. Expert.Rev.Med.Devices 3, 427-439.

Audran, R., Collet, B., Moisan, A., Toujas, L., 1995. Fate of mouse macrophages radiolabelled with PKH-95 and injected intravenously. Nucl.Med.Biol. 22, 817821.

Badie, B., Schartner, J., 2001. Role of microglia in glioma biology. Microsc.Res.Tech. $54,106-113$.

Badie, B., Schartner, J.M., 2000. Flow cytometric characterization of tumor-associated macrophages in experimental gliomas. Neurosurgery 46, 957-961.

Bajetto, A., Barbieri, F., Dorcaratto, A., Barbero, S., Daga, A., Porcile, C., Ravetti, J.L., Zona, G., Spaziante, R., Corte, G., Schettini, G., Florio, T., 2006. Expression of CXC chemokine receptors 1-5 and their ligands in human glioma tissues: Role of CXCR4 and SDF1 in glioma cell proliferation and migration. Neurochem.Int. 49, 423-432.

Bernaudin, M., Marti, H.H., Roussel, S., Divoux, D., Nouvelot, A., Mackenzie, E.T., Petit, E., 1999. A potential role for erythropoietin in focal permanent cerebral is chemia in mice. J.Cereb.Blood Flow Metab 19, 643-651.

Burke, B., 2003. Macrophages as novel cellular vehicles for gene therapy. Expert.Opin.Biol.Ther. 3, 919-924.

Burke, B., Sumner, S., Maitland, N., Lewis, C.E., 2002. Macrophages in gene therapy: cellular delivery vehicles and in vivo targets. J.Leukoc.Biol. 72, 417-428.

Chokri, M., Freudenberg, M., Galanos, C., Poindron, P., Bartholeyns, J., 1989. Antitumoral effects of lipopolysaccharides, tumor necrosis factor, interferon and activated macrophages: synergism and tissue distribution. Anticancer Res. 9, 1185-1190.

Clark, R.K., Lee, E.V., Fish, C.J., White, R.F., Price, W.J., Jonak, Z.L., Feuerstein, G.Z., Barone, F.C., 1993. Development of tissue damage, inflammation and resolution following stroke: an immunohistochemical and quantitative planimetric study. Brain Res.Bull. 31, 565-572. 
Crowther, M., Brown, N.J., Bishop, E.T., Lewis, C.E., 2001. Microenvironmental influence on macrophage regulation of angiogenesis in wounds and malignant tumors. J.Leukoc.Biol. 70, 478-490.

Ehtesham, M., Kabos, P., Kabosova, A., Neuman, T., Black, K.L., Yu, J.S., 2002. The use of interleukin 12-secreting neural stem cells for the treatment of intracranial glioma. Cancer Res. 62, 5657-5663.

Foster-Gareau, P., Heyn, C., Alejski, A., Rutt, B.K., 2003. Imaging single mammalian cells with a 1.5 T clinical MRI scanner. Magn Reson.Med. 49, 968-971.

Haase, A., 1990. Snapshot FLASH MRI. Applications to T1, T2, and chemical-shift imaging. Magn Reson.Med. 13, 77-89.

Heyn, C., Bowen, C.V., Rutt, B.K., Foster, P.J., 2005. Detection threshold of single SPIO-labeled cells with FIESTA. Magn Reson.Med. 53, 312-320.

Heyn, C., Ronald, J.A., Mackenzie, L.T., MacDonald, I.C., Chambers, A.F., Rutt, B.K., Foster, P.J., 2006. In vivo magnetic resonance imaging of single cells in mouse brain with optical validation. Magn Reson.Med. 55, 23-29.

Hill, J.M., Dick, A.J., Raman, V.K., Thompson, R.B., Yu, Z.X., Hinds, K.A., Pessanha, B.S., Guttman, M.A., Varney, T.R., Martin, B.J., Dunbar, C.E., McVeigh, E.R., Lederman, R.J., 2003. Serial cardiac magnetic resonance imaging of injected mesenchymal stem cells. Circulation 108, 1009-1014.

Hinds, K.A., Hill, J.M., Shapiro, E.M., Laukkanen, M.O., Silva, A.C., Combs, C.A., Varney, T.R., Balaban, R.S., Koretsky, A.P., Dunbar, C.E., 2003. Highly efficient endosomal labeling of progenitor and stem cells with large magnetic particles allows magnetic resonance imaging of single cells. Blood 102, 867-872.

Kadiu, I., Glanzer, J.G., Kipnis, J., Gendelman, H.E., Thomas, M.P., 2005. Mononuclear phagocytes in the pathogenesis of neurodegenerative diseases. Neurotox.Res. 8 , 25-50.

Krop, I.E., 2006. Chemokine signaling in gliomas: prognostic factor, therapeutic target or both? Cancer Biol.Ther. 5, 1039-1041.

Minchinton, A.I., Tannock, I.F., 2006. Drug penetration in solid tumours. Nat.Rev.Cancer 6, 583-592.

Modo, M., Hoehn, M., Bulte, J.W., 2005. Cellular MR imaging. Mol.Imaging 4, 143-164.

Modo, M., Mellodew, K., Cash, D., Fraser, S.E., Meade, T.J., Price, J., Williams, S.C., 2004. Mapping transplanted stem cell migration after a stroke: a serial, in vivo magnetic resonance imaging study. Neuroimage. 21, 311-317.

Moore, A., Marecos, E., Bogdanov, A., Jr., Weissleder, R., 2000. Tumoral distribution of long-circulating dextran-coated iron oxide nanoparticles in a rodent model. Radiology 214, 568-574.

Myers, R., Manjil, L.G., Cullen, B.M., Price, G.W., Frackowiak, R.S., Cremer, J.E., 1991. Macrophage and astrocyte populations in relation to [3H]PK 11195 binding in rat 
cerebral cortex following a local ischaemic lesion. J.Cereb.Blood Flow Metab 11, 314-322.

Nakamura, K., Ito, Y., Kawano, Y., Kurozumi, K., Kobune, M., Tsuda, H., Bizen, A., Honmou, O., Niitsu, Y., Hamada, H., 2004. Antitumor effect of genetically engineered mesenchymal stem cells in a rat glioma model. Gene Ther. 11, 11551164.

Ohlfest, J.R., Demorest, Z.L., Motooka, Y., Vengco, I., Oh, S., Chen, E., Scappaticci, F.A., Saplis, R.J., Ekker, S.C., Low, W.C., Freese, A.B., Largaespada, D.A., 2005. Combinatorial antiangiogenic gene therapy by nonviral gene transfer using the sleeping beauty transposon causes tumor regression and improves survival in mice bearing intracranial human glioblastoma. Mol.Ther. 12, 778-788.

Phillips, J.B., Williams, A.J., Adams, J., Elliott, P.J., Tortella, F.C., 2000. Proteasome inhibitor PS519 reduces infarction and attenuates leukocyte infiltration in a rat model of focal cerebral ischemia. Stroke 31, 1686-1693.

Sanai, N., Alvarez-Buylla, A., Berger, M.S., 2005. Neural stem cells and the origin of gliomas. N.Engl.J.Med. 353, 811-822.

Serganova, I., Doubrovin, M., Vider, J., Ponomarev, V., Soghomonyan, S., Beresten, T., Ageyeva, L., Serganov, A., Cai, S., Balatoni, J., Blasberg, R., Gelovani, J., 2004. Molecular imaging of temporal dynamics and spatial heterogeneity of hypoxiainducible factor-1 signal transduction activity in tumors in living mice. Cancer Res. 64, 6101-6108.

Shapiro, E.M., Sharer, K., Skrtic, S., Koretsky, A.P., 2006. In vivo detection of single cells by MRI. Magn Reson.Med. 55, 242-249.

Shapiro, E.M., Skrtic, S., Sharer, K., Hill, J.M., Dunbar, C.E., Koretsky, A.P., 2004. MRI detection of single particles for cellular imaging. Proc.Natl.Acad.Sci.U.S.A 101, 10901-10906.

Strik, H.M., Hulper, P., Erdlenbruch, B., Meier, J., Kowalewski, A., Hemmerlein, B., Gold, R., Bahr, M., 2006. Models of monocytic invasion in to glioma cell aggregates. Anticancer Res. 26, 865-871.

Strik, H.M., Stoll, M., Meyermann, R., 2004. Immune cell infiltration of intrinsic and metas tatic intracranial tumours. Anticancer Res. 24, 37-42.

Stroh, A., Zimmer, C., Werner, N., Gert, K., Weir, K., Kronenberg, G., Steinbrink, J., Mueller, S., Sie land, K., Dirnagl, U., Nickenig, G., Endres, M., 2006. Tracking of systemically administered mononuclear cells in the ischemic brain by high-field magnetic resonance imaging. Neuroimage. 33, 886-897.

Tabatabai, G., Bahr, O., Mohle, R., Eyupoglu, I.Y., Boehmler, A.M., W ischhusen, J., Rieger, J., Blumcke, I., Weller, M., Wick, W., 2005. Lessons from the bone marrow: how malignant glioma cells attract adult haematopoietic progenitor cells. Brain 128, 2200-2211. 
Tang, Y., Shah, K., Messerli, S.M., Snyder, E., Breakefield, X., Weissleder, R., 2003. In vivo tracking of neural progenitor cell migration to glioblastomas. Hum.Gene Ther. $14,1247-1254$.

Terreno, E., Geninatti, C.S., Belfiore, S., Biancone, L., Cabella, C., Esposito, G., Manazza, A.D., Aime, S., 2006. Effect of the intracellular localization of a Gdbased imaging probe on the relaxation enhancement of water protons. Magn Reson.Med. 55, 491-497.

Tsukamoto, Y., Kuwabara, K., Hirota, S., Ikeda, J., Stern, D., Yanagi, H., Matsumoto, M., Ogawa, S., Kitamura, Y., 1996. 150-kD oxygen-regulated protein is expressed in human atherosclerotic plaques and allows mononuclear phagocytes to withstand cellular stress on exposure to hypoxia and modified low density lipoprotein. J.Clin.Invest 98, 1930-1941.

Watanabe, T., Tanaka, R., Taniguchi, Y., Yamamoto, K., Ono, K., Yoshida, S., 1998. The role of microglia and tumor-primed lymphocytes in the interaction between $\mathrm{T}$ lymphocytes and brain endothelial cells. J.Neuroimmunol. 81, 90-97.

Wu, Y.L., Ye, Q., Foley, L.M., Hitchens, T.K., Sato, K., Williams, J.B., Ho, C., 2006. In situ labeling of immune cells with iron oxide particles: An approach to detect organ rejection by cellular MRI. Proc.Natl.Acad.Sci.U.S.A.

Zelivyanskaya, M.L., Nelson, J.A., Poluektova, L., Uberti, M., Mellon, M., Gendelman, H.E., Boska, M.D., 2003. Tracking superparamagnetic iron oxide labeled monocytes in brain by high-field magnetic resonance imaging. J.Neurosci.Res. 73, 284-295.

Zhang, Z., Jiang, Q., Jiang, F., Ding, G., Zhang, R., Wang, L., Zhang, L., Robin, A.M., Katakowski, M., Chopp, M., 2004. In vivo magnetic resonance imaging tracks adult neural progenitor cell targeting of brain tumor. Neuroimage. 23, 281-287. 
Table 1: $T_{1}, T_{2}$ and $T_{2}{ }^{*}$ values (2.35T) as a function of the iron in the incubating medium (mean $\pm s d ; n=3)$.

Cells were hydrolysed and immobilized in agarose.

\begin{tabular}{|cc|c|c|}
\hline $\begin{array}{c}\text { Concentration of iron } \\
(\mu \mathrm{g} / \mathrm{ml} / 2.5 \times 106 \text { cells })\end{array}$ & $\mathrm{T}_{1}(\mathrm{~ms})$ & $\mathrm{T}_{2}(\mathrm{~ms})$ & $\mathrm{T}_{2}{ }^{*}(\mathrm{~ms})$ \\
\hline 0 & $2640+/-276$ & $175+/-7$ & $153+/-51$ \\
\hline 6.3 & $2643+/-283$ & $175+/-7$ & $123+/-55$ \\
\hline 12.3 & $2670+/-221$ & $176+/-8$ & $127+/-58$ \\
\hline 31.7 & $2718+/-290$ & $164+/-6$ & $112+/-59$ \\
\hline 63.4 & $2650+/-207$ & $140+/-7$ & $25+/-11$ \\
\hline 158.4 & $2630+/-271$ & $133+/-6$ & $34+/-15$ \\
\hline
\end{tabular}

\section{Legends}

\section{Figure 1 : In vitro labelling of Mo/Ma with MPIOs.}

A-C. Phase-contrast (A), fluorescent (B) and merged (C) microscopic images of labelled cells. Scale bar: $20 \mu \mathrm{m}$.

D. Confocal detection of the MPIOs (green channel) and of the nucleus stained with propidium iodide (red channel).

E-F. Prussian staining in (E) control and in (F) labelled cells.

G. Flow cytometric analysis of cellular labelling on control and labelled cells at 488 $\mathrm{nm}$. Representative examples from three independent experiments. 
Figure 2. Characterisation of cellular viability after labelling

A. Cellular size as determined by fluorescence-activated cell sorting (FACS) on control and on labelled cells, using the forward scatter parameter (FSC-H).

B. Cellular proliferation determined by cell counting under phase-contrast microscope. Error bars: SD; *: Significant difference $(p<.05)$ between labelled and control cells at a particular time point.

C-D. Transmission of the MPIOs to daughter cells, as determined by FACS at days 1, 2, 3, and 4. Proliferating (C) and non-proliferating conditions (D). Representative examples from three independent experiments.

E. Log of the mean of the fluorescence intensity as a function of the log of the total cell number, under proliferating conditions.

Figure 3. Ex vivo characterization of the tumour colonization following intravenous injection of $\mathrm{Mo} / \mathrm{Ma}$

A. Ex vivo $\mathrm{T}_{2}{ }^{*}$-weighted $\mathrm{MR}$ image $(7 \mathrm{~T})$ of a rat brain bearing a tumour $(7$ days after implantation of the tumour cells and 3 days after administration of the Mo/Ma). Antero-posterior position of the slice was centred on bregma.

B-C. Lectin (B) and Prussian blue (C) staining after erythrosin counterstaining on adjacent coronal brain sections (from a region located at the tip of the white arrowhead on image A). Dark spots in lectin stained images indicate macrophages and microglia; Blue spots in Prussian blue stained images indicate iron. Pink erythrosin staining refers to cytosol. Scale bar: $100 \mu \mathrm{m}$.

D. Prussian blue staining after erythrosin counterstaining on spleen section taken from control rat (no Mo/Ma injection). No detectable blue spots from iron. Scale bar: $200 \mu \mathrm{m}$. 
E. Same as $D$, but spleen section taken from rat having been administered ironloaded Mo/Ma. Strong iron staining.

Representative examples from three independent experiments.

\section{Figure 4. In vivo determination of the specificity of the colonisation of the tumour}

A-C. Ex vivo $\mathrm{T}_{2}{ }^{*}$-weighted MR image $(2.35 \mathrm{~T})$ of a rat brain obtained at Day 9 after inoculation of tumour cells into the right striatum and saline injection into the left striatum. Labelled Mo/Ma were intravenously injected at Day 4. Antero-posterior position of the slices was centred on bregma. Black arrows indicate iron deposition along the injection tracts. In Fig. B, the white arrowhead points to the non-tumour striatum from which pathology image $D$ was taken, while the white arrow points to tumour area from which pathology image $E$ was taken.

D-E. Histological confirmation of the signal voids detected in the MR images. Prussian blue staining / erythrosin counterstained images of non-tumour (D) and tumour striatum (E). Blue dots indicate iron. Pink background indicates cytosol. Scale bar: $200 \mu \mathrm{m}$. Insets show the corresponding lectin stained images from adjacent sections (scale bar: $50 \mu \mathrm{m}$ ). Dark areas indicate macrophages and microglia.

F. Fluorescence image (Hoechst 33342 counterstaining of cell nuclei) of MPIOlabelled Mo/Ma in the tumour. Green spots indicate MPIOs. Scale bar: $200 \mu \mathrm{m}$.

Figure 5. In vivo detection within the tumour of intravenously injected Mo/Ma, at Day 7 of tumour growth

A-B. $T_{2}{ }^{*}$-weighted MR images $(2.35 \mathrm{~T})$ of a rat brain obtained 7 days after implantation of $\mathrm{C} 6$ tumour cells and 4 days after intravenous administration of labelled 
Mo/Ma (A) or saline (B). Antero-posterior position of the slice was centred on bregma. White arrow in image A points to iron-related hypointensity.

C-D. $T_{2}$-weighted MR images from the slices shown in $A$ and $B$, respectively.

E-G. Pathology images from tumour area delineated on image C.

E. Prussian blue stained - erythrosin counterstained image. Scale bar: $50 \mu \mathrm{m}$. Blue spots indicate iron. Inset shows an isolated Mo/Ma viewed at higher magnification factor (scale bar: $10 \mu \mathrm{m}$ ). Blue spots are located within the darker erythrosin stained area, indicative of cell cytoplasm.

F. Fluorescence image. Green spots indicate MPIOs.

G. Fluorescence image (F) merged with Hoechst 33342 counterstaining of cell nuclei. Scale bar: $200 \mu \mathrm{m}$.

Representative examples from 5 independent experiments.

Figure 6. In vivo detection with in the tumour of intravenously injected Mo/Ma, at Day 14 of tumour growth

A-C. $\mathrm{T}_{2}{ }^{*}$-weighted $\mathrm{MR}$ images $(2.35 \mathrm{~T}$ ) of a rat brain obtained 14 days after implantation of $\mathrm{C} 6$ tumour cells and 3 days after intravenous administration of labelled Mo/Ma (A-B; two different antero-posterior positions in the same animal) or saline (C). The slices shown in images $\mathrm{B}$ and $\mathrm{C}$ were centred on bregma.

E-F. $T_{2}$-weighted MR images from the slices shown in $B$ and $C$, respectively.

D. Prussian blue stained ) erythrosin counterstained image from the tumour area delineated in image E. Blue spots indicate iron. Pink background indicates cytosol. The dotted line indicates the tumour border. cc: corpus callosum; t: tumour; v: ventricle. Scale bar: $500 \mu \mathrm{m}$. 
Images are representative examples from 8 independent experiments (4 per group).

G. Histograms of $\mathrm{T}_{2}{ }^{*}$-weighted signal intensities encountered over the tumour volume, for the saline injected animals and the Mo/Ma injected animals. Tumours were delineated on the basis of $\mathrm{T}_{2}$-weighted images.

Figure 7. In vivo detection of the effect of haemorrhage on the MR images.

A-B. $\mathrm{T}_{2}{ }^{*}$-weighted $\mathrm{MR}$ images $(2.35 \mathrm{~T})$ of a rat brain obtained 7 days after implantation of $\mathrm{C} 6$ tumour cells and 4 days after intravenous administration of saline. Images were taken from two slices positioned differently in the rostro-caudal position.

C-D. Erythrosin stained pathology images from striatal (C) and cortical (D) regions that have been delineated on MR images $A$ and $B$, respectively. Haemorrhage is characterized by strong erythrosin staining. 
5. Figure

Click here to download high resolution image

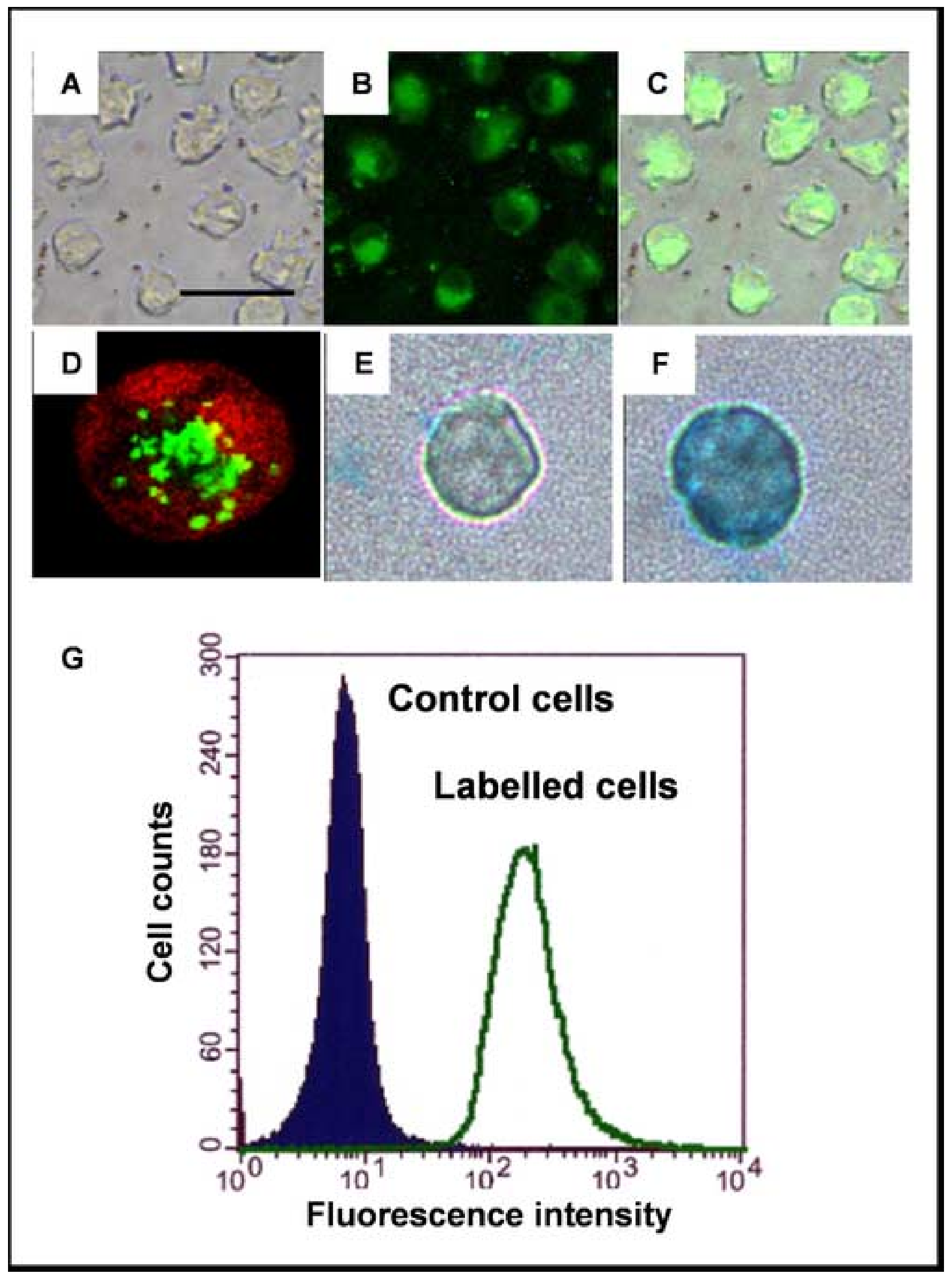

Fluorescence intensity 


\section{Figure}

Click here to download high resolution image

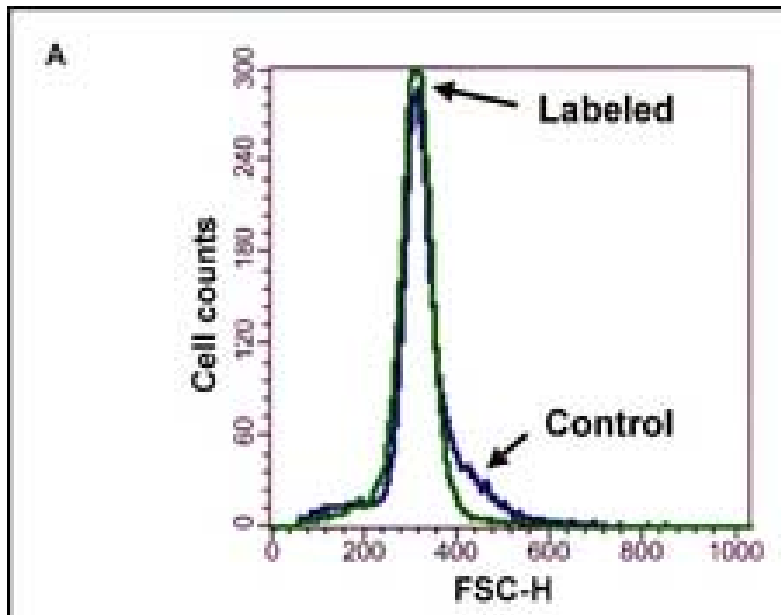

c
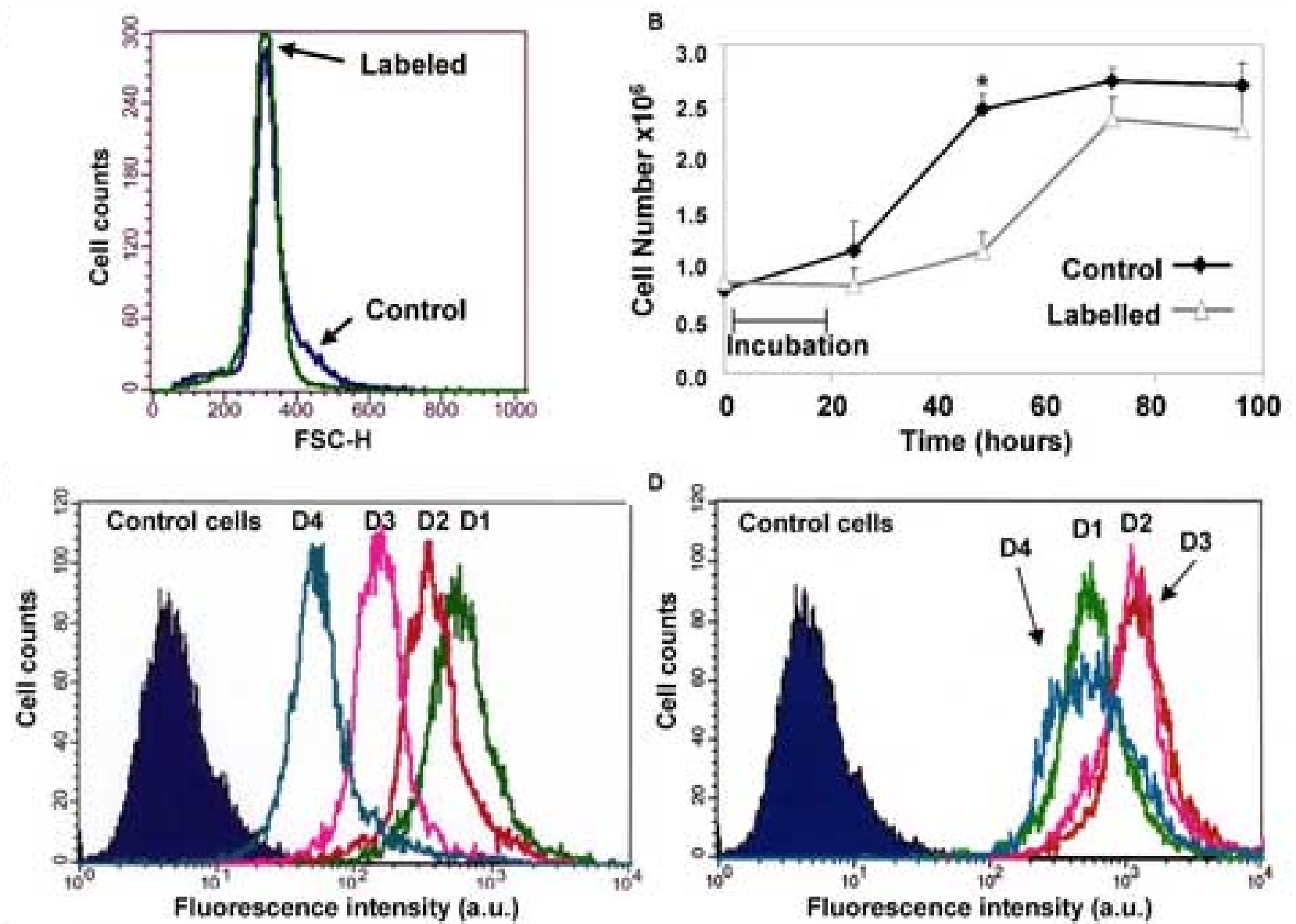

E

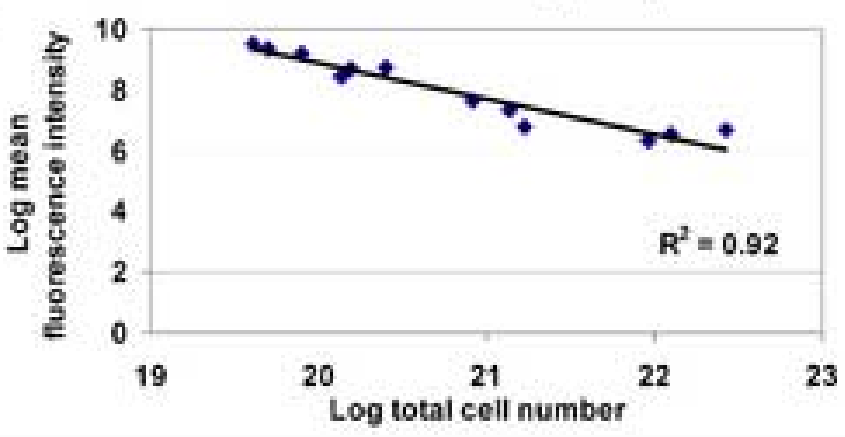

Fluorescence intensity (a.u.) 


\section{Figure}

Click here to download high resolution image

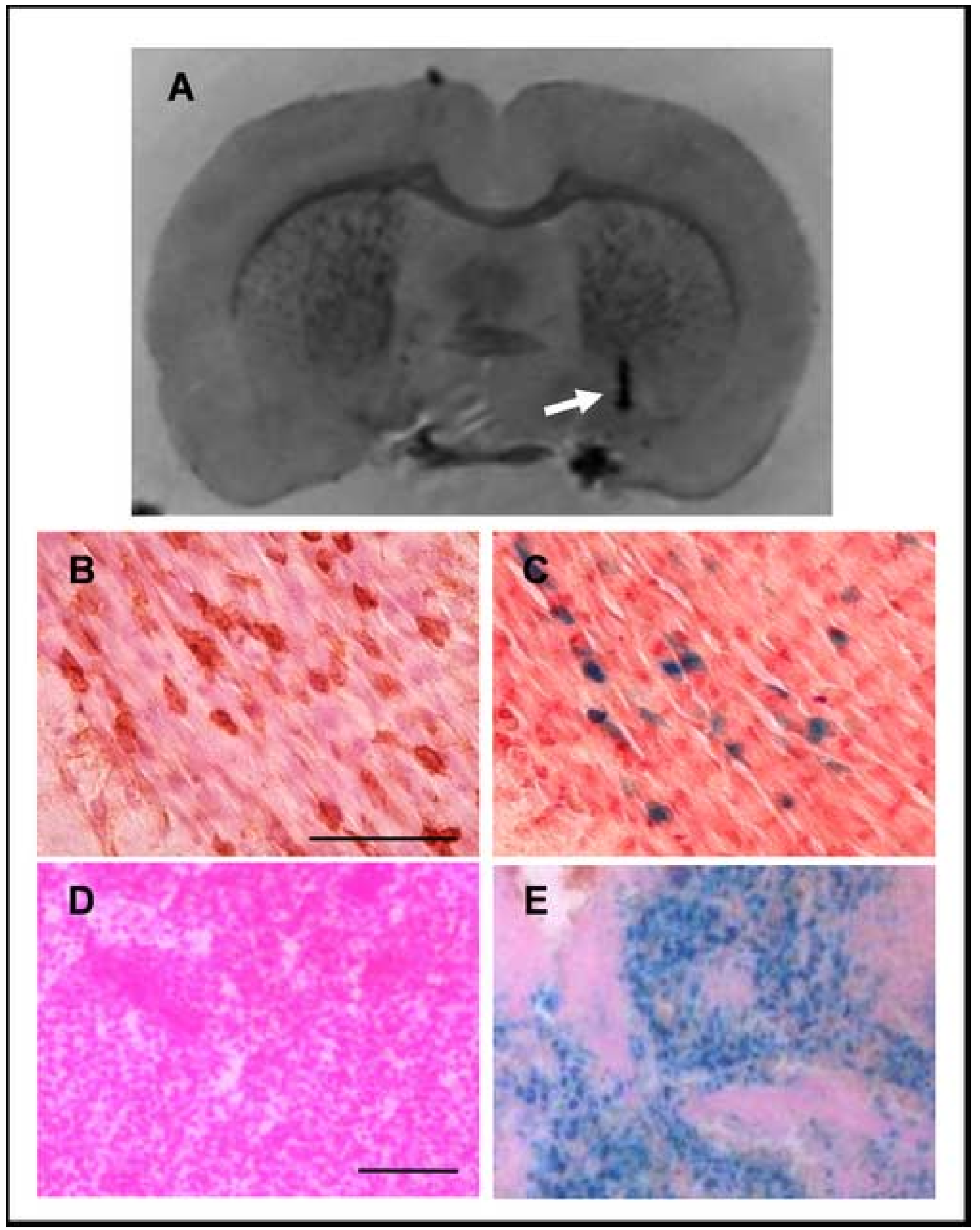


5. Figure
Click here to download high resolution image

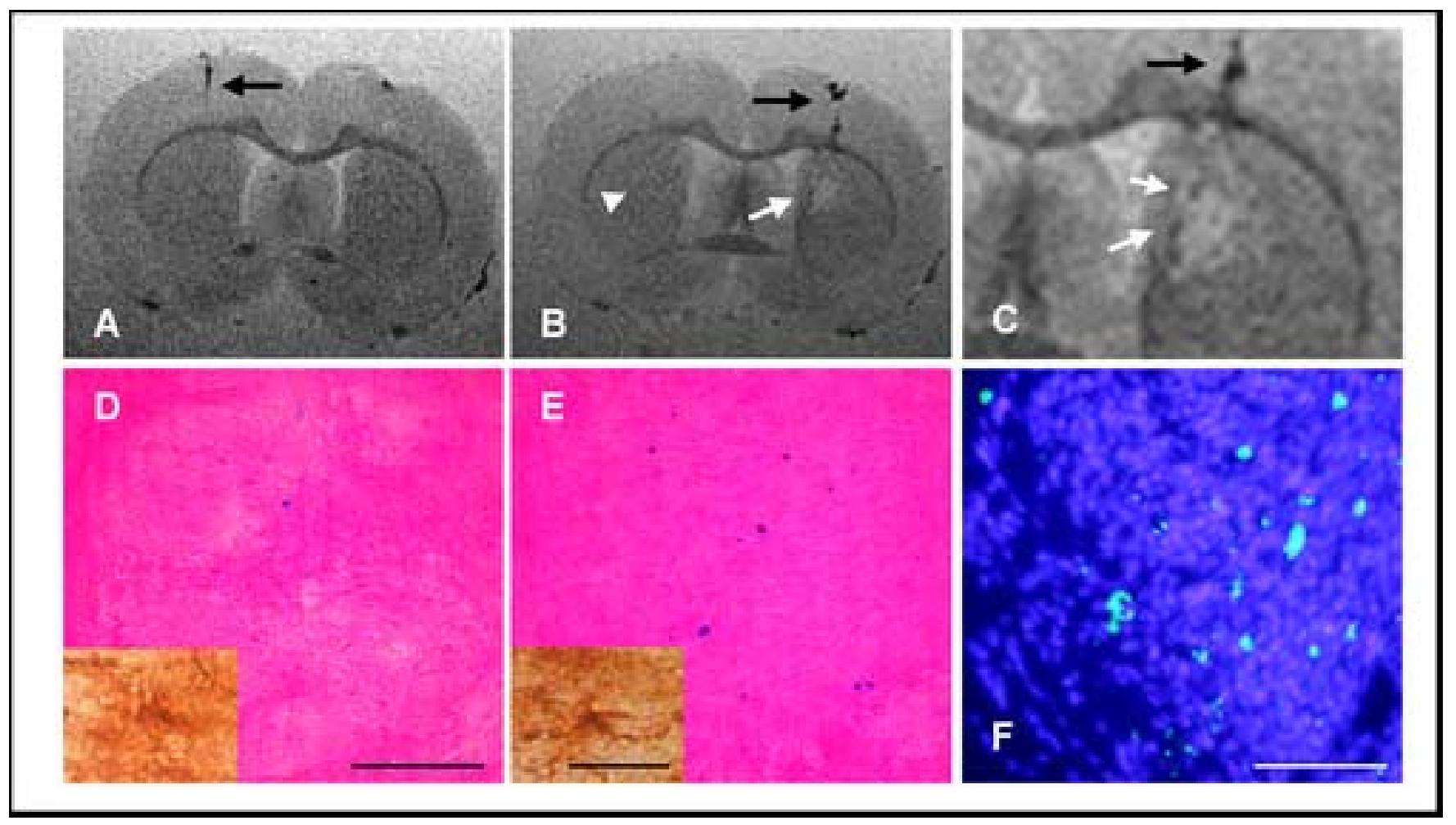



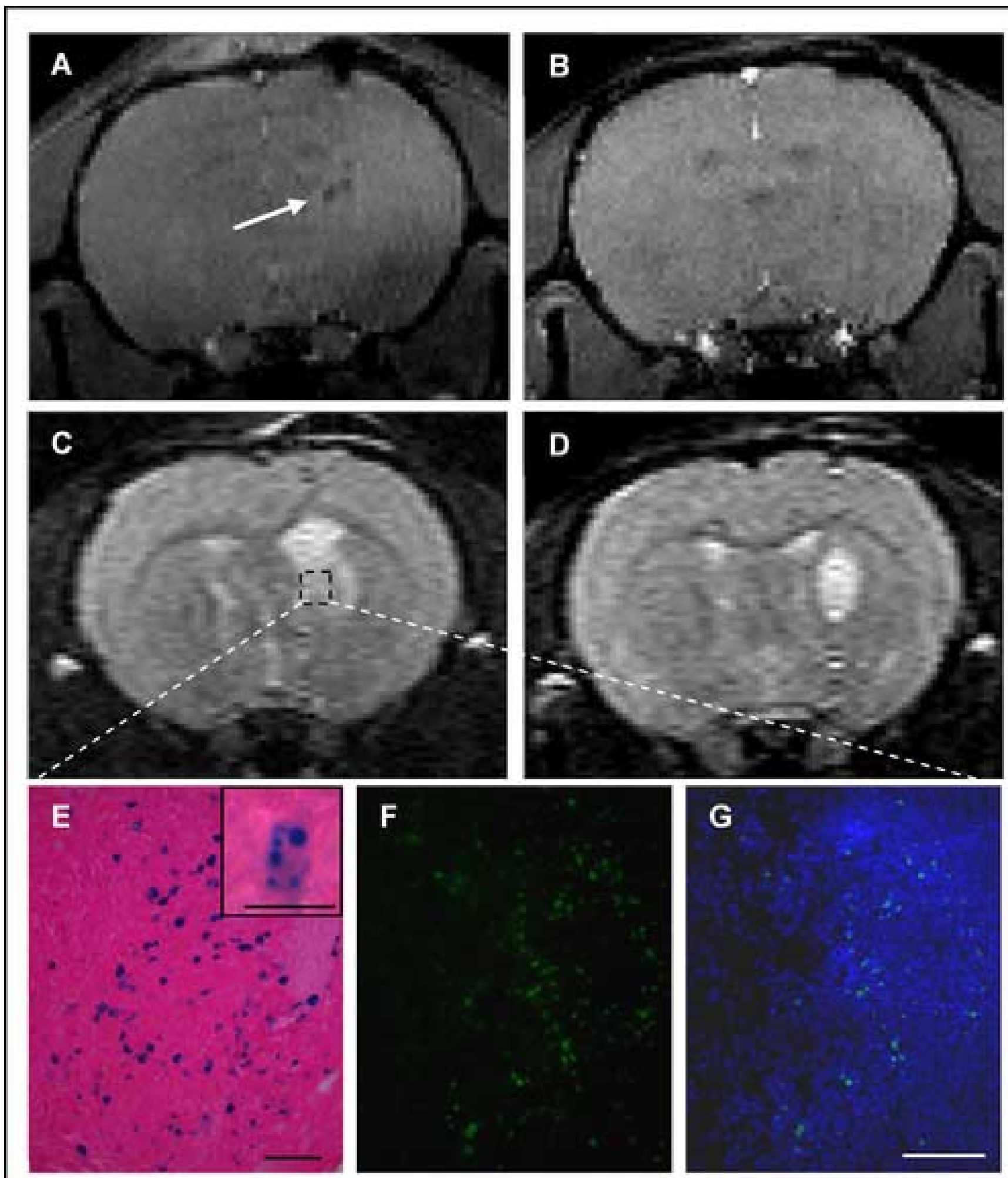

G

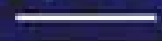


5. Figure

Click here to download high resolution image
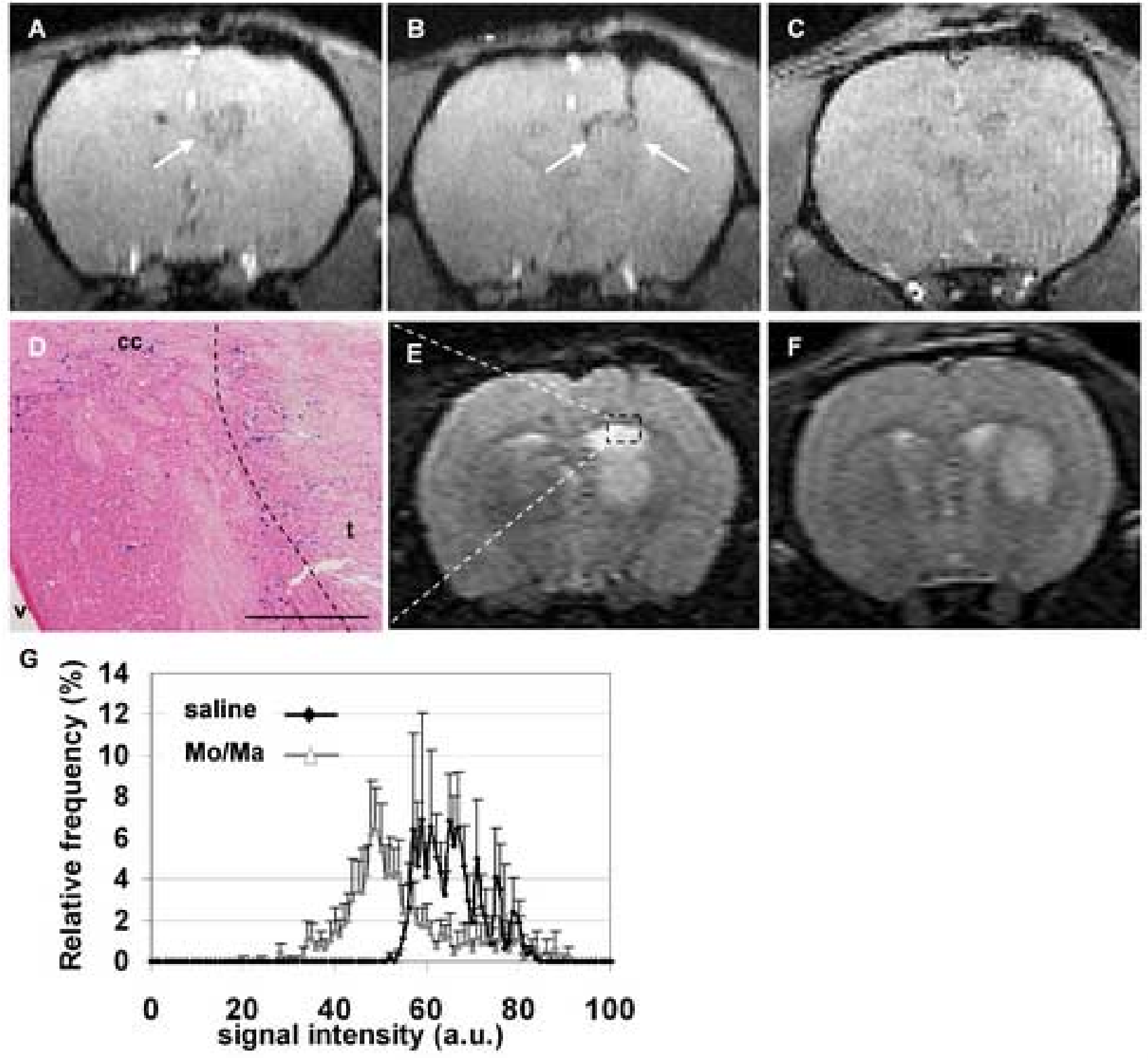
5. Figure
Click here to download high resolution image

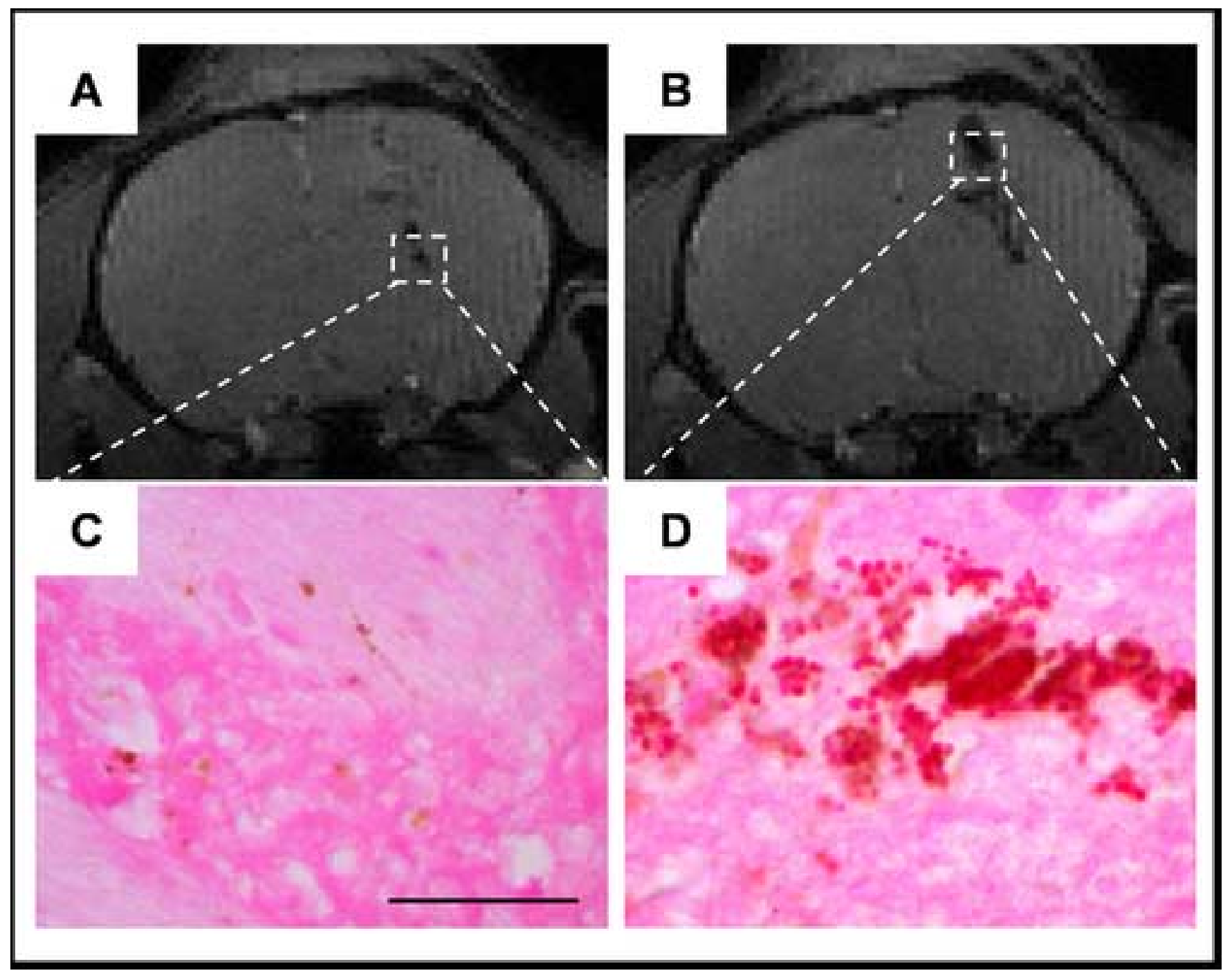

